\title{
Effects of N-Acetylcystein on HSCRP Level in Acute Myocardial Infarction Patients Receiving Fibrinolytic Therapy
}

\author{
Savithri Indriani ${ }^{1}$, Ahmad Yasa ${ }^{1}$, Trisulo Wasyanto ${ }^{1}$
}

IDepartment of Cardiology and Vascular Medicine, Faculty of Medicine, Universitas Sebelas Maret, RS Dr. Moewardi, Surakarta, Indonesia

\section{Correspondence:} dr Savithri Indriani Department of Cardiology and Vascular Medicine, Faculty of Medicine,

Universitas Sebelas Maret, RS Dr. Moewardi, Surakarta, Indonesia E-mail: savduckfatih@gmail.com

\begin{abstract}
Background: Worldwide, coronary heart disease (CHD) is a leading cause of death. Inflammation in CHD and acute myocardial infarction (AMI) is a trigger due to the formation of atheroma plaques in the coronary arteries. N-Acetylcysteine (NAC) can prevent inflammation, remodeling and left ventricular dysfunction, interstitial fibrosis, and improve survival. To determine the effect of NAC on hsCRP levels in patients with acute myocardial infarction who received fibrinolytic therapy.

Methods: This study was an experimental study with pre and post, single blind and randomization methods on the effect of NAC on hsCRP levels compared to controls carried out in July - August 2018 on the incidence of ST Elevation Myocardial Infarction (STEMI) came to Dr Moewardi Hospital and get fibrinolytic therapy.
\end{abstract}

Results: A total of 33 patients were included in this study, there were 15 patients (mean age $58.80 \pm 8.54$ years) of the control group and 18 patients (mean age $55.45 \pm 9.92$ years) the treatment group receiving additional therapy of NAC evervescent $600 \mathrm{mg}$ three times a day for three days. This study showed that hsCRP levels after intervention in the control and treatment groups were significantly different with $p=0.00 \mathrm{I}$. The level of hsCRP in the control group after administration of NAC had a median of II $4.50 \mathrm{mg} / \mathrm{L}(\mathrm{I} 8.60-300.00)$ while in the treatment group had a median of $18.75 \mathrm{mg} / \mathrm{L}(5.50$ - 102.90).

Conclusion: The addition of NAC $600 \mathrm{mg}$ of therapy three times daily for 3 days can reduce hsCRP levels in patients with STEMI receiving fibrinolytic therapy compared to patients with acute myocardial infarction with ST segment elevation who did not receive additional NAC therapy.

(Indonesian J Cardiol. 2018;39:145-I55)

Keywords: hsCRP, N-Acetylcysteine, acute myocardial infarction 


\title{
Pengaruh N-Acetylcystein Terhadap HSCRP Pada Pasien Infark Miokard Akut Dengan Elevasi Segmen St Yang Mendapat Terapi Fibrinolitik
}

\author{
Savithri Indriani ${ }^{1}$, Ahmad Yasa 1, Trisulo Wasyanto ${ }^{1}$
}

\begin{abstract}
Abstrak
Latar Belakang: Di seluruh dunia, penyakit jantung koroner (PJK) merupakan penyebab utama kematian. Inflamasi pada PJK dan infark miokard akut (IMA) merupakan pemicu akibat terbentuknya plak ateroma pada arteri koroner. N-Acetylcysteine (NAC) dapat mencegah inflamasi, remodeling dan disfungsi ventrikel kiri, fibrosis interstisial, dan meningkatkan survival untuk mengetahui pengaruh NAC terhadap kadar hsCRP pada pasien infark miokard akut yang mendapatkan terapi fibrinolitik.

Metode: Penelitian ini merupakan penelitian eksperimental dengan metode pre dan post, single blind dan randomisasi mengenai pengaruh NAC terhadap kadar hsCRP dibandingkan dengan kontrol yang dilakukan pada bulan Juli - Agustus 2018 terhadap paien Infark Miokard Akut dengan Elevasi Segmen ST (IMA-EST) yang datang ke Rumah Sakit Dr Moewardi dan mendapat terapi fibrinolitik.

Hasil: Sebanyak 33 pasien diikutsertakan pada penelitian ini, terdapat 15 pasien (rerata usia $58.80 \pm 8.54$ tahun) kelompok kontrol dan 18 pasien (rerata usia 55.45 \pm 9.92 tahun) kelompok perlakuan yang mendapat terapi tambahan NAC evervescent $600 \mathrm{mg}$ tiga kali sehari selama tiga hari. Penelitian ini menunjukkan bahwa kadar hsCRP sesudah dilakukan intervensi pada kelompok kontrol dan perlakuan berbeda bermakna dengan nilai $\mathrm{p}=0.001$. Kadar hsCRP pada kelompok kontrol sesudah pemberian NAC memiliki median $114.50 \mathrm{mg} / \mathrm{L}(18.60$ - 300.00) sedangkan pada kelompok perlakuan memiliki median 18.75 $\mathrm{mg} / \mathrm{L}(5.50$ - 102.90).

Kesimpulan: Pemberian terapi tambahan NAC 600 mg tiga kali sehari selama 3 hari dapat menurunkan kadar hsCRP pada pasien infark miokard akut dengan elevasi segmen ST yang mendapat terapi fibrinolitik dibanding pasien infark miokard akut dengan elevasi segmen ST yang tidak mendapat terapi tambahan NAC.
\end{abstract}

(Indonesian J Cardiol. 2018;39:145-155)

Kata Kunci: hsCRP, N-Acetylcysteine, infark miokard akut

\footnotetext{
IDepartemen Ilmu Penyakit Jantung dan Pembuluh Darah, Fakultas Kedokteran, Universitas Sebelas Maret, RS Dr. Moewardi, Surakarta, Indonesia

Korespondensi:

dr Savithri Indriani

Department of Cardiology and Vascular Medicine, Faculty of Medicine, Universitas Sebelas Maret, RS Dr. Moewardi, Surakarta, Indonesia E-mail: savduckfatih@gmail.com
}

\section{Pendahuluan}

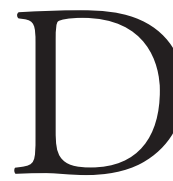

i seluruh dunia, penyakit jantung koroner (PJK) merupakan penyebab utama kematian $^{1}$. Penyakit jantung koroner saat ini menjadi penyebab hampir 1,8 juta kematian setiap tahunnya, atau $20 \%$ dari semua 
kematian di Eropa 2. Di Amerika Serikat insidensi infark miokard akut dengan elevasi segmen ST (IMAEST) menurun dari 133 per 100.000 pada tahun 1999 menjadi 50 per 100.000 pada tahun 2008, sedangkan insidensi dari infark miokard akut non-elevasi segmen ST (IMA-NEST) tetap konstan atau sedikit meningkat ${ }^{3}$.

Sedangkan di Indonesia, kematian akibat penyakit kardiovaskuler semakin meningkat setiap tahunnya dan penyakit kardiovaskular ini merupakan penyebab kematian terbanyak di Indonesia ${ }^{4}$. Sebelumnya IMA lebih sering terjadi pada negara maju, namun saat ini kejadian IMA semakin meningkat pada negara berkembang ${ }^{5}$. Data yang diperoleh dari Jakarta Acute Coronary Syndrome (JAC) Registry dari tahun 20082009 didapatkan 2013 pasien sindroma koroner akut, dimana 654 pasien menderita IMA-EST dan 622 pasien menderita IMA-NEST dirawat di Pusat Jantung Nasional Harapan Kita ${ }^{4}$.

Inflamasi pada penyakit jantung koroner (PJK) dan infark miokard akut (IMA) merupakan pemicu akibat terbentuknya plak ateroma pada arteri koroner. Mekanisme kompleks terbentuknya plak ateroma ditengarai diinisiasi oleh inflamasi mulai dari disfungsi endotel hingga timbulnya instabilitas dan ruptur plak

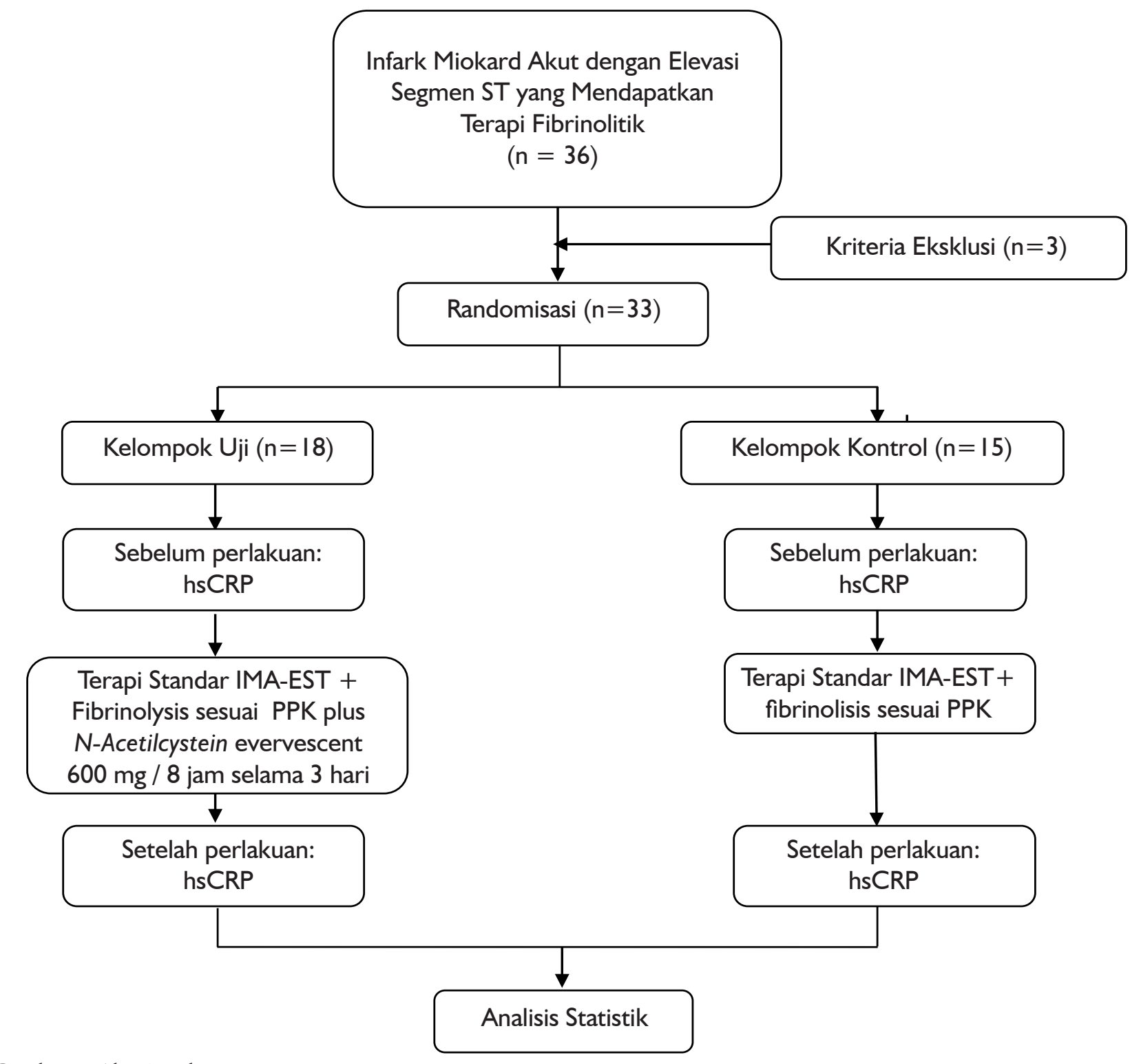

Gambar 1. Alur Penelitian. 
Tabel 1. Karakteristik dasar subyek penelitian

\begin{tabular}{|c|c|c|c|}
\hline Variabel & $\begin{array}{c}\text { Kontrol } \\
(\mathrm{n}=15)\end{array}$ & $\begin{array}{c}\text { Perlakuan } \\
(\mathrm{n}=18)\end{array}$ & Nilai $\mathrm{p}$ \\
\hline \multicolumn{4}{|l|}{ DEMOGRAFIS } \\
\hline \multicolumn{4}{|l|}{ Jenis Kelamin } \\
\hline Laki-laki n, (\%) & $12(80)$ & 17 (94.4) & 0.465 \\
\hline Perempuan n, (\%) & $3(20)$ & $1(5.6)$ & \\
\hline Umur & $58.80 \pm 8.54$ & $55.45 \pm 9.92$ & 0.311 \\
\hline \multicolumn{4}{|l|}{ FAKTOR RISIKO } \\
\hline Hipertensi n, (\%) & $10(66.7)$ & $11(61.1)$ & 1.000 \\
\hline Merokok n, (\%) & $9(60)$ & $14(77.8)$ & 0.468 \\
\hline Diabetes melitus n, (\%) & $1(6.7)$ & $6(33.3)$ & 0.150 \\
\hline Dislipidemia $\mathrm{n},(\%)$ & $2(13,3)$ & $5(27,8)$ & 0.560 \\
\hline Riwayat Keluarga n, (\%) & $0(0)$ & $1(5.6)$ & 1.000 \\
\hline \multicolumn{4}{|l|}{ KONDISI KLINIS } \\
\hline Indeks MassaTubuh( $\mathrm{m} / \mathrm{kg} 2)$ & $24.02 \pm 2.19$ & $23.85 \pm 2.45$ & 0.603 \\
\hline Awitan $\leq 6(j a m) \quad n,(\%)$ & $13(86.7)$ & $14(77.8)$ & 0.837 \\
\hline Kelas Killip I n, (\%) & $8(53.3)$ & $12(66.7)$ & 0.672 \\
\hline Kelas Killip II-IV n, (\%) & $7(46.7)$ & $6(33.3)$ & \\
\hline IMA EST Anterior n, (\%) & $7(46.7)$ & $12(66.7)$ & 0.421 \\
\hline IMA EST Inferior n, (\%) & $8(53.3)$ & $6(33.3)$ & \\
\hline \multicolumn{4}{|c|}{ PARAMETER LABORATORIUM } \\
\hline hsTroponin I & $1713(5.8-34659)$ & $3901(35.5-50000)$ & 0.563 \\
\hline Glukosa sewaktu(mg/dL) & $136.33 \pm 31.26$ & $156.33 \pm 63.08$ & 0.023 \\
\hline eGFR (mg/dL) & $63(35-207)$ & $65(10-109)$ & 0.612 \\
\hline Kolesterol total (mg/dL) & $159(124-553)$ & $111.5(57-197)$ & 0.175 \\
\hline \multicolumn{4}{|c|}{ PARAMETER EKOKARDIOGRAFI } \\
\hline LVEF (Simpson, \%) & $45.26 \pm 7.55$ & $46.38 \pm 10.89$ & 0.217 \\
\hline \multicolumn{4}{|l|}{ TERAPI } \\
\hline Fibrinolitik berhasil n, (\%) & $4(26.7)$ & $2(11.1)$ & 0.484 \\
\hline Tindakan IKP n, (\%) & $6(40)$ & $5(27.8)$ & 0.711 \\
\hline Nitrat $n,(\%)$ & $2(13.3)$ & $12(66.7)$ & 0.006 \\
\hline Ace inhibitor n, (\%) & $15(100)$ & $18(100)$ & 1.000 \\
\hline B Blocker n, (\%) & $14(93.3)$ & $13(72.2)$ & 0.266 \\
\hline Statin n, (\%) & $15(100)$ & $18(100)$ & 1.000 \\
\hline
\end{tabular}

ateroma serta peningkatan aktivitas kaskade koagulasi (Packard and Libby, 2007 dan Hansson, 2005). Salah satu parameter yang mudah diukur untuk menilai derajat inflamasi pada infark miokard akut adalah dengan pengukuran $C$ reactive protein (CRP) suatu protein fase akut yang diproduksi terutama oleh hepatosit di bawah pengaruh sitokin proinflamasi seperti interleukin (IL)-6 dan tumor necrosis factor-alpha (TNF- $\alpha)^{8}$. Peningkatan kadar reaktan fase akut pada pasien dengan sindroma koroner akut (SKA) tampaknya menjadi penanda dari inflamasi vaskular dan hiperresponsivitas sistem inflamasi bahkan pada rangsangan yang kecil ${ }^{9}$. Beberapa penelitian telah menunjukkan bahwa kadar
CRP dalam serum dapat memprediksi risiko kejadian akut kardiovaskuler berulang di rumah sakit ${ }^{10}$ atau mortalitas 30 hari atau jangka panjang pada IMAEST $^{11}$.

$N$-Acetylcysteine (NAC) dapat mencegah inflamasi, remodeling dan disfungsi ventrikel kiri, fibrosis interstisial, dan meningkatkan survival pada penelitian pada hewan (Waard et al., 2009). Telah dibuktikan bahwa NACdapat juga mengurangi iskemia reperfusi, cedera, aritmia dan perluasan infark. Agen trombolitik pada pasca-infark miokard akut dapat menyebabkan cedera reperfusi dengan manifestasi myocardialstunning, aritmia, kerusakan miokard dan perluasan ukuran 
infark. NACdalam kombinasi dengan streptokinase secara signifikan dapat mengurangi stres oksidatif dan meningkatkan fungsi ventrikel pada pasien dengan infark miokard ${ }^{12}$.

Pada pasien dengan IMA EST yang dilakukan fibrinolitik, pemberian NACdapat mengurangi kadar matriks metalloproteinase (MMP)-9 dan 2 yang berperan dalam remodeling jantung pasca-infark sekaligus mengurangi major adverse cardiac events (MACE) dalam follow-up satu tahun secara bermakna ${ }^{13}$. Pengurangan ukuran infark juga terjadi secara bermakna dengan pemberian NAC pada pasien IMA-EST yang dilakukan tindakan intervensi koroner perkutan (IKP) primer $^{14}$.

Sepengetahuan penulis, sampai saat ini belum ada penelitian mengenai pengaruh tambahan terapi $N$-Acetylcystein oral terhadap kadar hsCRP pada pasien infark miokard akut yang mendapat terapi fibrinolitik.

\section{Metode}

\section{Subjek}

Penelitian ini merupakan penelitian eksperimental dengan metode pre dan post, single blind dan randomisasi (randomized control trial). Penelitian ini dilakukan pada populasi pasien IMA-EST yang mendapatkan terapi fibrinolitik yang menjalani perawatan di ICVCU RSUD dr. Moewardi, Surakarta, Jawa Tengah pada bulan Juli Agustus 2018. Pasien yang menderita episode pertama dari IMA-EST merupakan sindroma klinis yang didefinisikan dengan ditemukannya gejala khas nyeri dada sebagai gejala iskemia miokard yang berhubungan dengan gambaran EKG berupa elevasi segmen ST dihitung dari titik J pada setidaknya 2 sadapan yang bersebelahan $\geq 2 \mathrm{~mm}(0.2 \mathrm{mV})$ pada laki-laki atau $\geq 1.5$ $\mathrm{mm}(0.15 \mathrm{mV})$ pada wanita di sadapan V2-V3 dan atau $\geq 1 \mathrm{~mm}(0.1 \mathrm{mV})$ di sadapan lain di dada atau sadapan ekstremitas dan pelepasan biomarker nekrosis miokard 15. Pengambilan sampel dari populasi dilakukan secara berurutan (concecutive sampling). Alokasi intervensi sampel dilakukan secara acak sederhana (simple random sampling) menggunakan undian.

Pasien dengan riwayat miokard infark sebelumnya, gagal jantung kronik, disfungsi katup, gagal ginjal kronik, penyakit hati, inflamasi kronis atau keganasan, tiroid, infeksi akut atau sepsis, stroke akut dan pasien yang meninggal $<72$ jam masa perawatan dikeluarkan dari penelitian. Selain itu, pasien dengan infeksi akut atau kronis saat ini, atau penyakit autoimun, mereka yang telah menjalani operasi prosedur dalam 3 bulan terakhir, dan yang menerima pengobatan dengan obat anti-inflamasi, suplemen, dan antioksidan juga dikeluarkan dari penelitian.

Sampel pada studi ini total 33 pasien (15 pasien kontrol, 18 pasien perlakuan), diperiksa kadar hsCRP pada saat daang di IGD dan 72 jam paska serangan. Data demografi pasien termasuk usia, jenis kelamin, riwayat medis, keterlambatan pra-rumah sakit, waktu iskemik (didefinisikan karena keterlambatan pra-rumah sakit ditambahkan oleh waktu ke jarum atau balon), parameter hemodinamik pada saat masuk, faktor risiko untuk kejadian jantung, riwayat obat, elektrokardiogram (EKG) dicatat. Semua pasien dipantau dan dievaluasi setiap hari di ruang rawat inap selama masa studi. Evaluasi ekokardiografi dilakukan di semua pasien selama mereka dirawat di rumah sakit.

Semua kelompok dilakukan pengambilan sampel darah intravena $30-60$ menit sebelum tindakan fibrinolisis untuk mengetahui kadar hsCRP. Pengambilan sampel darah intravena sebanyak $4 \mathrm{ml}$ menggunakan spuit $5 \mathrm{ml}$, kemudian dimasukkan ke dalam tabung sentrifus dan dibiarkan membeku. Sampel darah yang sudah membeku dipusingkan selama 5-10 menit dengan kecepatan 400 rpm untuk mendapatkan serum darah. Serum darah disimpan dalam tabung khusus kemudian dibekukan pada suhu $-80{ }^{\circ} \mathrm{C}$ untuk dilakukan pemeriksaan kadar hsCRP secara bersamaan.

Pada kelompok perlakuan, sebelum dilakukan tindakan fibrinolisis diberikan $N$-Acetylcystein $600 \mathrm{mg}$ evervescent (Fluimucil ${ }^{\circledR}$, Zambon Swtzerland Ltd.) dilanjutkan tiap 8 jam selama 3 hari. Untuk kelompok kontrol sebelum dilakukan tindakan fibrinolisis dan selama 3 hari tidak diberikan $N$-Acetylcystein. Semua kelompok dilakukan tindakan fibrinolisis menggunakan preparat Streptokinase 1,5 juta unit yang diencerkan dalam $100 \mathrm{cc} \mathrm{NaCl}$ dan dimasukkan secara intra vena selama 30-60 menit. Observasi dilakukan 72 jam setelah tindakan fibrinolisis. Setelah 72 jam setelah tindakan fibrinolisis dilakukan pengambilan sampel darah intravena untuk mengetahui kadar hsCRP. Pengambilan sampel darah intravena sebanyak $4 \mathrm{ml}$ menggunakan spuit $5 \mathrm{ml}$, kemudian dimasukkan ke dalam tabung sentrifus dan dibiarkan membeku. Sampel darah yang sudah membeku dipusingkan selama 5-10 menit 
dengan kecepatan 400 rpm untuk mendapatkan serum darah. Serum darah disimpan dalam tabung khusus kemudian dibekukan pada suhu $-20^{\circ} \mathrm{C}$ untuk dilakukan pemeriksaan kadar hsCRP secara bersamaan. Serum hsCRP (Cobas, Roche Diagnostics GmbH, Jerman) diukur menggunakan enzyme immunoassay pada sampel serum saat pasien datang dan 72 jam post fibrinolysis.

\section{Analisis Statistik}

Data disajikan dalam bentuk mean \pm SD kemudian dianalisis menggunakan SPSS 22.0 for windows dengan nilai $\mathrm{p}<0,05$ dianggap signifikan secara statistik. Digunakan uji beda mean. Untuk mengetahui beda mean antara kelompok perlakuan dan kontrol sebelum dan sesudah perlakuan digunakan uji t sampel independen bila distribusi data normal (bila tidak normal digunakan uji mann whitney).

\section{Hasil}

Penelitian ini dimaksudkan untuk mengetahui pengaruh pemberian NAC $600 \mathrm{mg}$ tiga kali sehari selama 3 hari terhadap kadar hsCRP pada pasien IMA-EST yang mendapat terapi fibrinolitik. Subjek penelitian berjumlah 36 orang dari 36 orang ini 3 orang dieksklusi karena meninggal dalam masa perawtan $<72$ jam. 33 orang sampel dibagi dalam dua kelompok yaitu kelompok kontrol sebanyak 15 orang dan kelompok perlakuan 18 orang. Pada penelitian ini, kelompok perlakuan diberikan NAC $600 \mathrm{mg}$ evervescent tiap 8 jam selama 3 hari, sedangkan kelompok kontrol tidak diberikan N-Acetylcysteine (lihat Gambar 1).

Dilakukan pemeriksaan uji homogenitas pada variabel subjek penelitian untuk mengetahui normalitas distribusi sampel penelitian dengan uji KolmogorovSmirnov. Jika distribusi data variable bersifat normal, maka membandingkan variable subjek penelitian yang tidak berpasangan antara kontrol dan perlakuan menggunakan jenis analisis statistik parametrik yaitu uji T Independent. Namun apabila distribusi data bersifat tidak normal, maka uji beda menggunakan jenis analisis statistik non parametrik yaitu uji Mann-Whitney, dan apabila data binomial menggunakan uji Chi Square.

Variabel umur responden menunjukkan nilai ratarata 58.80 tahun untuk kontrol dengan simpang baku 8.54 tahun Variabel usia dari kelompok perlakuan menunjukkan rerata 55.44 tahun dengan simpang baku 9.92 tahun. Uji Kolmogorov-Smirnov menunjukkan data bersifat normal sehingga dilanjutkan dengan uji beda rerata menggunakan independent t-test untuk menguji adakah perbedaan yang bermakna diantara dua kelompok sampel. Uji independent t-test menghasilkan $\mathrm{p}=0.311(\mathrm{p}>0,05)$. Hasil ini menunjukkan bahwa uji beda rerata menggunakan independent $t$-test tidak bermakna dan dapat diartikan bahwa rata-rata umur kedua kelompok sampel tidak berbeda secara bermakna.

Selain umur sebagai karakteristik demografis, pengujian homogenitas juga dilakukan terhadap variabel karakteristik klinis yang meliputi jenis kelamin, faktor resiko hipertensi, merokok, DM, Dislipidemia, riwayat keluarga, indeks massa tubuh, awitan, kelas Killip, jenis IMA-EST, hsTrop I, Hb, Ht, Leukosit, Trombosit, GDS, eGFR, kadar kolesterol total, LDL,HDL,trigliserida, fraksi ejeksi (Simpson), keberhasilan fibrinolitik, dilakukan tindakan IKP atau tidak, pemberian ACE inhibitor, $\beta$ Blocker, Nitrat dan Statin. Masing - masing variable diuji normalitas untuk mengetahui distribusi datanya, kemudian dilanjutkan degan uji beda variablevariabel tersebut antara kontrol dan perlakuan. (Tabel 5). Kadar hsTrop I, eGFR, Kolesterol total, LDL dan Trigliserid bersifat tidak normal, sehingga uji beda variabel antara kontrol dan perlakuan dilakukan dengan menggunakan uji Mann Whitney.

Dari subjek penelitian, didapat 21 pasien memiliki faktor resiko hipertensi dimana 10 pasien $(66.7 \%)$ dari kelompok perlakuan dan 11 pasien (61.1\%) dari kelompok kontrol. Data binomial ini kemudian dilakukan uji komparatif non parametrik menggunakan Chi-Square untuk menguji adakah perbedaan yang bermakna diantara dua kelompok sampel. Dari uji Chi-Square didapatkan nilai $\mathrm{p}=1.000(\mathrm{p}>0,05)$. Hasil ini menunjukkan bahwa uji komparatif menggunakan uji Chi-Square tidak bermakna yang dapat diartikan bahwa proporsi pasien yang memiliki faktor resiko hipertensi diantara dua kelompok tidak berbeda bermakna. Variabel lain yang bersifat binomial seperti jenis kelamin, faktor resiko hipertensi, merokok, DM, dyslipidemia, riwayat keluarga, awitan, kelas Killip, diagnosa IMAEST anterior atau inferior, kesuksesan pemberian fibrinolitik, dilakukan tindakan IKP, pemberian nitrat, ACE inhibitor, $\beta$ Blocker dan statin yang didapat dilakukan uji yang sama dan ditunjukkan pada tabel1. 
Pembuktian hipotesis mengenai pengaruh pemberian NAC $600 \mathrm{mg}$ tiga kali sehari selama 3 hari terhadap kadar hsCRP pada pasien Infark Miokard Akut dilakukan dalam empat tahap, yaitu :

\section{Uji beda rerata kadar hsCRP sebelum pemberian NAC antara kelompok kontrol dan kelompok perlakuan.}

Variabel kadar hsCRP sebelum pemberian NAC pada kelompok kontrol berdistribusi normal, sementara variabel kadar hsCRP kelompok perlakuan sebelum pemberian NAC berdistribusi tidak normal. Dengan demikian uji beda rerata kadar hsCRP antara kelompok kontrol dan kelompok perlakuan sebelum pemberian NAC menggunakan uji Mann Whitney.

Hasil uji Mann Whitney menunjukkan bahwa pada kelompok kontrol hsCRP sebelum pemberian NAC memiliki median $5.500 \mathrm{mg} / \mathrm{L}$ dengan batas minimum - maksimum 1.40 - $16.40 \mathrm{mg} / \mathrm{L}$, sedangkan pada kelompok perlakuan hsCRP sebelum pemberian NAC memiliki median $2.500 \mathrm{mg} / \mathrm{L}$ dengan batas minimum - maksimum 1.20 - 90.90 mg/L. Uji Mann Whitney menghasilkan $\mathrm{p}=0.492$. Hasil ini menunjukkan bahwa uji beda rerata menggunakan Mann Whitney tidak bermakna atau dapat diartikan bahwa kadar hsCRP sebelum dilakukan intervensi pada kelompok kontrol dan perlakuan tidak berbeda bermakna, seperti yang ditunjukkan pada tabel 2 .

Tabel 2. Perbandingan hsCRP sebelum pemberian NAC antara kelompok kontrol dan kelompok perlakuan

\begin{tabular}{lccc}
\hline & $\begin{array}{c}\text { Median } \\
(\text { minimum }- \\
\text { maksimum })\end{array}$ & $\begin{array}{c}\text { Mean } \\
\text { Rank }\end{array}$ & $\begin{array}{c}\text { Nilai } \\
\mathrm{p}\end{array}$ \\
\hline Kontrol $(\mathrm{n}=15)$ & $5.50(1.40-16.40)$ & 18.27 & 0.492 \\
Perlakuan $(\mathrm{n}=18)$ & $2.50(1.20-9.90)$ & 15.94 & \\
\hline
\end{tabular}

Uji beda rerata kadar hsCRP sebelum dan sesudah pemberian NAC pada kelompok kontrol

Variabel kadar hsCRP sebelum pemberian NAC pada kelompok kontrol berdistribusi normal, sementara variabel kadar hsCRP kelompok kontrol setelah pemberian NAC berdistribusi tidak normal. Dengan demikian uji beda rerata untuk sampel berpasangan dilakukan dengan uji Wilcoxon.

Hasil uji Wilcoxon menunjukkan bahwa pada kelompok kontrol hsCRP sebelum pemberian NAC memiliki median $5.500 \mathrm{mg} / \mathrm{L}$ dengan batas minimum - maksimum 1.40 - $16.40 \mathrm{mg} / \mathrm{L}$, sedangkan pada kelompok kontrol hsCRP setelah pemberian NAC memiliki median $114.50 \mathrm{mg} / \mathrm{L}$ dengan batas minimum - maksimum 18.60 - 300.00 mg/L. Uji Wilcoxon menghasilkan $\mathrm{p}=0.001$, karena nilai $\mathrm{p}<0.05$ maka uji beda rerata menggunakan Wilcoxon scara statistik terdapat perbedaan yang bermakna atau dapat diartikan bahwa kadar hsCRP sebelum dan sesudah dilakukan intervensi pada kelompok kontrol berbeda bermakna, seperti yang ditunjukkan pada tabel 3 .

Tabel 3. Perbandingan hsCRP sebelum dan sesudah pemberian NAC pada kelompok kontrol.

\begin{tabular}{ccc} 
Variabel $)$ & $\begin{array}{c}\text { Median } \\
(\text { minimum }- \text { maksimum })\end{array}$ & $\begin{array}{c}\text { Nilai } \\
\mathrm{p}\end{array}$ \\
\hline $\begin{array}{c}\text { hsCRP sebelum pemberian } \\
\text { NAC }(\mathrm{n}=15)\end{array}$ & $5.50(1.40-16.40)$ & \\
hsCRP setelah pemberian & & 0.001 \\
NAC $(\mathrm{n}=15)$ & $114.50(18.60-300.00)$ & \\
\hline
\end{tabular}

Uji beda rerata kadar hsCRP sebelum dan sesudah pemberian NAC pada kelompok perlakuan

Variabel kadar hsCRP sebelum pemberian NAC pada kelompok perlakuan berdistribusi tidak normal, sementara variabel kadar hsCRP kelompok perlakuan setelah pemberian NAC juga berdistribusi tidak normal. Dengan demikian uji beda rerata untuk sampel berpasangan dilakukan dengan uji Wilcoxon.

Hasil uji Wilcoxon menunjukkan bahwa pada kelompok perlakuan hsCRP sebelum pemberian NAC memiliki median $2.50 \mathrm{mg} / \mathrm{L}$ dengan batas minimum - maksimum 1.20 - $90.90 \mathrm{mg} / \mathrm{L}$, sedangkan pada kelompok perlakuan hsCRP setelah pemberian NAC memiliki median $18.75 \mathrm{mg} / \mathrm{L}$ dengan batas minimum - maksimum 5.50 - 102.90 mg/L. Uji Wilcoxon menghasilkan $\mathrm{p}=0.001$, karena nilai $\mathrm{p}<0.05$ maka uji beda rerata menggunakan Wilcoxon scara statistik terdapat perbedaan yang bermakna atau dapat diartikan bahwa kadar hsCRP sebelum dan sesudah dilakukan intervensi pada kelompok perlakuan berbeda bermakna, seperti yang ditunjukkan pada tabel 4 . 
Tabel 4. Perbandingan hsCRP sebelum dan sesudah pemberian NAC pada kelompok perlakuan.

\begin{tabular}{ccc} 
Variabel $)$ & $\begin{array}{c}\text { Median } \\
(\text { minimum }- \text { maksimum })\end{array}$ & $\begin{array}{c}\text { Nilai } \\
\mathrm{p}\end{array}$ \\
\hline $\begin{array}{c}\text { hsCRP sebelum pemberian } \\
\text { NAC }(\mathrm{n}=18)\end{array}$ & $2.50(1.20-90.9)$ & \\
hsCRP setelah pemberian & & 0.001 \\
NAC $(\mathrm{n}=18)$ & $18.75(5.50-102.90)$ & \\
\hline
\end{tabular}

\section{Uji beda rerata kadar hsCRP sesudah pemberi- an NAC pada kelompok kontrol dan perlakuan}

Variabel kadar hsCRP sesudah pemberian NAC pada kelompok kontrol berdistribusi tidak normal, demikian pula dengan variabel kadar hsCRP kelompok perlakuan sesudah pemberian NAC berdistribusi tidak normal. Dengan demikian uji beda rerata kadar hsCRP antara kelompok kontrol dan kelompok perlakuan sesudah pemberian NAC menggunakan uji Mann Whitney.

Hasil uji Mann Whitney menunjukkan hsCRP pada kelompok kontrol sesudah pemberian NAC memiliki median $114.50 \mathrm{mg} / \mathrm{L}$ dengan batas minimum - maksimum 18.60 - $300.00 \mathrm{mg} / \mathrm{L}$, sedangkan pada kelompok perlakuan hsCRP sesudah pemberian NAC memiliki median $18.75 \mathrm{mg} / \mathrm{L}$ dengan batas minimum - maksimum 5.50 - 102.90 mg/L. Uji Mann Whitney menghasilkan $\mathrm{p}=0001$, karena nilai $\mathrm{p}<0.05$ maka uji beda rerata menggunakan uji Mann Whitney scara statistik terdapat perbedaan yang bermakna atau dapat diartikan bahwa kadar hsCRP sesudah dilakukan intervensi pada kelompok kontrol dan perlakuan berbeda bermakna, seperti yang ditunjukkan pada tabel5.

Tabel 5. Perbandingan hsCRP sesudah pemberian NAC antara kelompok kontrol dan kelompok perlakuan

\begin{tabular}{lccc}
\hline \multicolumn{1}{c}{ Variabel } & $\begin{array}{c}\text { Median } \\
(\text { minimum }- \\
\text { maksimum })\end{array}$ & $\begin{array}{c}\text { Mean } \\
\text { Rank }\end{array}$ & $\begin{array}{c}\text { Nilai } \\
\mathrm{p}\end{array}$ \\
\hline Kontrol $(\mathrm{n}=15)$ & $114.50(18.60-300.00)$ & 23.33 & 0.001 \\
Perlakuan $(\mathrm{n}=18)$ & $18.75(5.50-102.90)$ & 11.72 & \\
\hline
\end{tabular}

\section{Uji beda rerata delta-hsCRP pada kelompok kontrol dan kelompok perlakuan}

Variabel kadar delta-hsCRP pada kelompok kontrol berdistribusi tidak normal, demikian pula dengan variabel kadar delta-hsCRP kelompok perlakuan berdistribusi tidak normal. Dengan demikian uji beda rerata kadar delta-hsCRP antara kelompok kontrol dan kelompok perlakuan menggunakan uji Mann Whitney.

Hasil uji Mann Whitney menunjukkan delta-hsCRP pada kelompok kontrol sesudah pemberian NAC memiliki median $106.80 \mathrm{mg} / \mathrm{L}$ dengan batas minimum - maksimum 16.70 - 285.20 mg/L, sedangkan pada kelompok perlakuan delta-hsCRP sesudah pemberian NAC memiliki median $15.15 \mathrm{mg} / \mathrm{L}$ dengan batas minimum - maksimum 3.60 - 85.10 mg/L. Uji Mann Whitney menghasilkan $\mathrm{p}=0001$, karena nilai $\mathrm{p}<0.05$ maka uji beda rerata menggunakan uji Mann Whitney scara statistik terdapat perbedaan yang bermakna atau dapat diartikan bahwa kadar delta-hsCRP sesudah dilakukan intervensi pada kelompok kontrol dan perlakuan berbeda bermakna, seperti yang ditunjukkan pada tabel 6.

Tabel 6. Perbandingan delta-hsCRP sesudah pemberian NAC antara kelompok kontrol dan kelompok perlakuan

\begin{tabular}{lccc}
\hline \multicolumn{1}{c}{ Variabel } & $\begin{array}{c}\text { Median } \\
(\text { minimum }- \\
\text { maksimum })\end{array}$ & $\begin{array}{c}\text { Mean } \\
\text { Rank }\end{array}$ & $\begin{array}{c}\text { Nilai } \\
\mathrm{p}\end{array}$ \\
\hline Kontrol $(\mathrm{n}=15)$ & $106.80(16.70-285.20)$ & 23.40 & 0.001 \\
Perlakuan $(\mathrm{n}=18)$ & $15.15(3.60-85.10)$ & 11.57 & \\
\hline
\end{tabular}

Sehinggahipotesisyangmenyatakanbahwa "Pemberian terapi tambahan $N$-Acetylcystein dengan dosis $3 \times 600$ mg selama 3 hari dapat menurunkan kadar hsCRP pada pasien infark miokard akut dengan elevasi segmen ST yang medapatkan terapi fibrinolitik dibanding yang tidak mendapatkan NAC " dapat dibuktikan kebenarannya.

\section{Diskusi}

Penelitian ini adalah penelitian eksperimental dengan metode pre dan post studi disain yang bertujuan untuk mengetahui pengaruh pemberian $N$-Acetylcystein dengan dosis 3x600 mg selama 3 hari dapat menurunkan kadar hsCRP pada pasien infark miokard akut dengan elevasi segmen ST yang medapatkan terapi fibrinolitik.

Di seluruh dunia, penyakit jantung koroner (PJK) merupakan penyebab utama kematian ${ }^{1}$. Penyakit jantung koroner saat ini menjadi penyebab hampir 1,8 
juta kematian setiap tahunnya, atau 20\% dari semua kematian di Eropa 2. Di Amerika Serikat insidensi infark miokard akut dengan elevasi segmen ST (IMAEST) menurun dari 133 per 100.000 pada tahun 1999 menjadi 50 per 100.000 pada tahun 2008, sedangkan di Indonesia, kematian akibat penyakit kardiovaskuler semakin meningkat setiap tahunnya dan penyakit kardiovaskular ini merupakan penyebab kematian terbanyak di Indonesia ${ }^{4}$. Lebih dari tiga juta orang diperkirakan menderita IMA-EST dan lebih dari empat juta orang menderita IMA-NEST. Sebelumnya IMA lebih sering terjadi pada negara maju, namun saat ini kejadian IMA semakin meningkat pada negara berkembang 5 . Data yang diperoleh dari Jakarta Acute Coronary Syndrome (JAC) Registry dari tahun 20082009 didapatkan 2013 pasien sindroma koroner akut, dimana 654 pasien menderita IMA-EST dan 622 pasien menderita IMA-NEST dirawat di Pusat Jantung Nasional Harapan Kita4.

Inflamasi pada penyakit jantung koroner (PJK) dan infark miokard akut (IMA) merupakan pemicu terbentuknya plak ateroma pada arteri koroner. Salah satu parameter yang mudah diukur untuk menilai derajat inflamasi pada infark miokard akut adalah dengan pengukuran $\mathrm{C}$ reactive protein $(\mathrm{CRP})$ suatu protein fase akut yang diproduksi terutama oleh hepatosit di bawah pengaruh sitokin proinflamasi seperti interleukin (IL)-6 dan tumor necrosis factor-alpha (TNF- $\alpha$ ) 8 . Beberapa penelitian telah menunjukkan bahwa kadar CRP dalam serum dapat memprediksi risiko kejadian akut kardiovaskuler berulang di rumah sakit 10 atau mortalitas 30 hari atau jangka panjang pada IMAEST ${ }^{11}$.

$N$-Acetylcystein (NAC) dapat mencegah inflamasi, remodeling dan disfungsi ventrikel kiri, fibrosis interstisial, dan meningkatkan survival pada penelitian pada hewan ${ }^{16}$. Telah dibuktikan bahwa NAC dapat juga mengurangi iskemia reperfusi, cedera aritmia dan perluasan infark. Agen trombolitik pada pasca-infark miokard akut dapat menyebabkan cedera reperfusi dengan manifestasi myocardial stunning, cedera aritmia, kerusakan miokard dan perluasan ukuran infark. NAC dalam kombinasi dengan streptokinase secara signifikan dapat mengurangi stres oksidatif dan meningkatkan fungsi ventrikel pada pasien dengan infark miokard ${ }^{12}$.

Pada pasien dengan IMA EST yang dilakukan fibrinolitik, pemberian NAC dapat mengurangi kadar matriks metalloproteinase (MMP)-9 dan 2 yang berperan dalam remodeling jantung pasca-infark sekaligus mengurangi major adverse cardiac events (MACE) dalam follow-up satu tahun secara bermakna ${ }^{13}$. Pengurangan ukuran infark juga terjadi secara bermakna dengan pemberian NAC pada pasien IMA EST yang dilakukan tindakan intervensi koroner perkutan (IKP) primer14. Hasil penelitian ini diharapkan membuka strategi baru penatalaksanaan Infark Miokard Akut dengan penambahan NAC $600 \mathrm{mg} 3 \mathrm{x} /$ hari selama tiga hari pada terapi standar dapat memberikan keluaran yang lebih baik pada pasien infark miokard akut, karena terjadinya penurunan inflamasi yang ditandai dengan penurunan kadar hsCRP.

Temuan dari penelitian ini menunjukkan bahwa kadar hsCRP sebelum pemberian NAC pada kelompok kontrol dan perlakuan tidak berbeda bermakna. Namun kadar hsCRP memiliki nilai median lebih tinggi pada kelompok kontrol yaitu $5.50 \mathrm{mg} / \mathrm{L}$ dibandingkan dengan kelompok perlakuan yaitu $2.50 \mathrm{mg} / \mathrm{L}$. Kadar hsCRP kelompok kontrol maupun kelompok perlakuan sebelum pemberian NAC lebih rendah dari kadar hsCRP 72 jam sesudah pemberian NAC. Median kadar hsCRP kelompok kontrol sesudah pemberian NAC adalah $114.50 \mathrm{mg} / \mathrm{L}$, sedangkan pada kelompok perlakuan hsCRP sesudah pemberian NAC memiliki median $18.75 \mathrm{mg} / \mathrm{L}$. Hal ini sesuai teori, nilai hsCRP awal merepresentasikan low-grade inflamasi sebelumnya. Walau begitu menurut penelitian Makrygiannis et al., 2013 nilai hsCRP awal merupakan prediktor independen kematian jantung dan infark miokard baru non fatal pada pasien IMA-EST yang mendapat terapi fibrinolisis ${ }^{11}$.

Temuan lain dari penelitian ini menunjukkan bahwa kadar hsCRP sesudah dilakukan intervensi pada kelompok kontrol dan perlakuan berbeda bermakna dengan nilai $\mathrm{p}=0.001$. Kadar hsCRP pada kelompok kontrol sesudah pemberian NAC memiliki median $114.50 \mathrm{mg} / \mathrm{L}$ sedangkan pada kelompok perlakuan memiliki median $18.75 \mathrm{mg} / \mathrm{L}$. Hasil lain menunjukkan kadar delta-hsCRP sesudah dilakukan intervensi pada kelompok kontrol dan perlakuan berbeda bermakna dengan nilai $\mathrm{p}=0.001$. Delta hsCRP adalah selisih kadar hsCRP sebelum intervensi dan setelah intervensi. Kadar delta-hsCRP pada kelompok kontrol sesudah pemberian NAC memiliki median $106.80 \mathrm{mg} / \mathrm{L}$, sedangkan pada kelompok perlakuan delta-hsCRP 
sesudah pemberian NAC memiliki median $15.15 \mathrm{mg} / \mathrm{L}$. Hal ini menunjukkan bahwa kadar hsCRP maupun delta-hsCRP setelah intervensi lebih rendah pada kelompok perlakuan dibandingkan kelompok kontrol.

Hal ini selaras dengan teori bahwa NAC memiliki sifat anti-inflamasi ${ }^{17}$. Induksi faktor transkripsi proinflamasi activator protein-1 (AP-1) dan nuclear factor$\kappa \mathrm{B}(\mathrm{NF}-\kappa \mathrm{B})$ dihambat oleh $N$-Acetylcysteine. Faktorfaktor transkripsi ini terinduksi sebagai respon terhadap stres oksidatif sehingga mendukung argumen bahwa sifat anti-inflamasi NAC adalah karena mekanisme kerjanya sebagai antioksidan ${ }^{18,19}$. Berbagai penelitian juga menunjukan pemberian NAC dapat menghambat berbagai petanda inflamasi seperti TNF- $\alpha$, IL-6, IL3 , high sensitivity c-reactive protein ( $\mathrm{hsCRP}$ ), C3, dan soluble intercellular adhesion molecule (sICAM). Telah dibuktikan bahwa NAC dapat juga mengurangi iskemia reperfusi, cedera aritmia dan perluasan infark. Agen trombolitik pada pasca-infark miokard akut dapat menyebabkan cedera reperfusi dengan manifestasi myocardial stunning, aritmia, kerusakan miokardial dan perluasan ukuran infark. NAC dalam kombinasi dengan streptokinase secara signifikan mengurangi stres oksidatif dan meningkatkan fungsi ventrikel pada pasien dengan infark miokard ${ }^{12}$. Pemberian bersamaan dari NAC dan terapi reperfusi pada infark miokard secara signifikan mengurangi stres oksidatif dengan penurunan konsentrasi plasma hidroperoksida 20. Pengurangan ukuran infark dan terjaganya fungsi ventrikel kiri telah dilaporkan setelah infus NAC selama trombolisis. NAC merupakan sebuah antioksidan poten yang bisa secara langsung mengeliminasi radikal-radikal hidroksil. Dengan bekerja pada vascular cell adhesion molecules-1 dan adhesivitas yang dimediasi oleh endotelium, NAC mengurangi efek merugikan dari stress oksidatif. Lebih lagi, NAC mengurangi lesi oksidatif di dalam jaringan target, sehingga memungkinkan komsumsi oksigen yang cukup dan meningkatkan oksigenasi secara keseluruhan 13. Kesimpulannya, melalui aksinya sebagai anti inflamasi, NAC menyebabkan penurunan kadar hsCRP. Keuntungan terjadinya penurunan inflamasi dengan penambahan obat NAC adalah mengurangi iskemia reperfusi, cedera aritmia, kerusakan miokardial dan perluasan infark 12,13. Selain itu penurunan inflamasi pada pasien IMA dapat menurunkan progresifitas remodeling jantung yang merugikan sehingga mengurangi kejadian gagal jantung akibat IMA ${ }^{21}$.

\section{Keterbatasan Penelitian}

\section{Penelitian ini mempunyai keterbatasan yaitu :}

a. Penelitian ini hanya pada satu center, perlu dilakukan pada multicenter dengan jumlah sampel yang lebih banyak untuk menambah kekuatan peneltian.

b. Penelitian ini hanya fokus pada inflamasi pasien infark miokard akut, perlu dilakukan penelitian lebih lanjut terhadap luaran klinis seperti terjadinya infark miokard akut berulang, penurunan kejadian gagal jantung, atau kematian, serta penelitian yang lebih lama dengan desain kohort.

\section{Kesimpulan}

Pemberian terapi tambahan NAC $600 \mathrm{mg}$ tiga kali sehari selama 3 hari dapat menurunkan kadar hsCRP pada pasien infark miokard akut dengan elevasi segmen ST yang mendapat terapi fibrinolitik dibanding pasien infark miokard akut dengan elevasi segmen ST yang tidak mendapat terapi tambahan NAC.

\section{Persetujuan Etik}

Penelitian ini adalah hasil karya sendiri, dan semua sumber yang dikutip maupun dirujuk telah dinyatakan dengan benar dan telah lolos kaji etik.

\section{Persetujuan untuk Publikasi}

Semua pihak telah menyetujui publikasi penelitian ini.

\section{Konflik Kepentingan}

Tidak ada konflik kepentingan dalam pelaksanaan penelitian ini

\section{Pendanaan}

Pendanaan penelitian ini dari dana pribadi peneliti.

\section{Daftar Pustaka}

1. Hartley A, Marshall DC, Salciccioli JD, Sikkel MB, Maruthappu M, Shalhoub J. Trends in mortality from ischemic heart disease and cerebrovas- 
cular disease in Europe: 1980 to 2009. Circulation. 2016;133(20):1916-1926.

2. Townsend N, Wilson L, Bhatnagar P, Wickramasinghe K, Rayner M, Nichols M. Cardiovascular disease in Europe: Epidemiological update 2016. Eur Heart J. 2016;37(42):3232-3245.

3. Mozaffarian D, Benjamin EJ, Go AS, et al. Heart Disease and Stroke Statistics-2015 Update : A Report from the American Heart Association. Vol 131.; 2015.

4. Dharma S, Juzar DA, Firdaus I, Soerianata S. Acute myocardial infarction system of care in the third world. Neth Hear J. 2012;20(6):254-259.

5. White HD, Chew DP. Acute myocardial infarction. Lancet. 2008;372(9638):570-584.

6. Packard RRS, Libby P. Inflammation in Atherosclerosis: From Vascular Biology to Biomarker Discovery and Risk Prediction. Clin Chem. 2007;54(1):2438.

7. Hansson G. Inflammation, Atherosclerosis, and Coronary Artery Disease. $N$ Engl J Med. 2005;352:1685-1695.

8. Kushner I. The Acute Phase Response. Curr Contents. 1982;40:16.

9. Liuzzo G, Biasucci LM, Gallimore JR, et al. Enhanced inflammatory response in patients with preinfarction unstable angina. J Am Coll Cardiol. 1999;34(6):1696-1703.

10. Tomoda H, Aoki N. Prognostic value of C-reactive protein levels within six hours after the onset of acute myocardial infarction. Am Heart J. 2000;140(2):324-328.

11. Makrygiannis SS, Ampartzidou OS, Zairis MN, et al. Prognostic usefulness of serial c-reactive protein measurements in st-elevation acute myocardial infarction. Am J Cardiol. 2013;111(1):26-30.

12. Yesilbursa D, Serdar A, Senturk T, Serdar Z, Sağ $S$, Cordan J. Effect of $\mathrm{N}$-acetylcysteine on oxidative stress and ventricular function in patients with myocardial infarction. Heart Vessels. 2006;21(1):3337.

13. Talasaz AH, Khalili H, Fahimi F, et al. Effects of $\mathrm{N}$-acetylcysteine on the cardiac remodeling biomarkers and major adverse events following acute myocardial infarction: A randomized clinical trial. Am J Cardiovasc Drugs. 2014;14(1):51-61.

14. Pasupathy S, Tavella R, Grover S, et al. Early use of N-Acetylcysteine (NAC) with Nitrate Therapy in Pa- tients Undergoing Primary Percutaneous Coronary Intervention for ST-Segment Elevation Myocardial Infarction Reduces Myocardial Infarct Size (The NACIAM Trial). Circulation.2017;136(10):894-903.

15. O'Gara PT, Kushner FG, Ascheim DD, et al. 2013 ACCF/AHA guideline for the management of ST-elevation myocardial infarction: a report of the American College of Cardiology Foundation/ American Heart Association Task Force on Practice Guidelines. J Am Coll Cardiol. 2013;61(4):e78-140.

16. Waard M, Velden J, Boontje N. Detrimental effect of combined exercise training and eNOS overexpression on cardiac function after myocardial infarction. Am J Physiol Hear Circ Physiol. 2009;296(5):15131523.

17. Zuin R, Palamidese a, Negrin R. High-dose N-acetylcysteine in patients with exacerbations of chronic obstructive pulmonary disease. Clin drug .... 2005;25(6):401-408. http://link.springer.com/article/10.2165/00044011-200525060-00005.

18. Pinkus R, Weiner L, Daniel V. Role of oxidants and antioxidants in the induction of AP-1, NF- $\kappa \mathrm{B}$, and glutathione $\mathrm{S}$-transferase gene expression. J Biol Chem. 1996;271:13422-13429.

19. Radomska D, Skopiński P. N-acetylcysteine as an anti-oxidant and anti-inflammatory drug and its some clinical applications. Centr Eur J Immunol. 2012;37(1):57-66.

20. Sajkowska A, Wykretowicz A, Szczepanik A. Fibrinolytic therapy and N-Acetylcysteine in the treatment of patients with acute myocardial infarction: its influence on authentic plasma hydroperoxide levels and polymorphonuclear neutrophil oxygen metabolism. Cardiology. 1999;91(1):60-65.

21. Westman P, Lipinski M, Luger D, et al. Inflammation as a Driver of Adverse Left Ventricular Remodeling After Acute Myocardial Infarction. JACC. 2016;67(17):2050-2060. 